University of Michigan Law School University of Michigan Law School Scholarship Repository

Articles

Faculty Scholarship

2002

\title{
The Conundrum of Children, Confrontation, and Hearsay
}

Richard D. Friedman

University of Michigan Law School, rdfrdman@umich.edu

Available at: https://repository.law.umich.edu/articles/157

Follow this and additional works at: https://repository.law.umich.edu/articles

Part of the Constitutional Law Commons, Courts Commons, Criminal Procedure Commons, Evidence Commons, and the Juvenile Law Commons

\section{Recommended Citation}

Friedman, Richard D. "The Conundrum of Children, Confrontation, and Hearsay." Law \& Contemp. Probs. 65, no. 1 (2002): 243-55.

This Article is brought to you for free and open access by the Faculty Scholarship at University of Michigan Law School Scholarship Repository. It has been accepted for inclusion in Articles by an authorized administrator of University of Michigan Law School Scholarship Repository. For more information, please contact mlaw.repository@umich.edu. 


\title{
THE CONUNDRUM OF CHILDREN, CONFRONTATION, AND HEARSAY
}

\author{
RICHARD D. FRIEDMAN*
}

INTRODUCTION

The adjudication of child abuse claims poses an excruciatingly difficult conundrum. The crime is a terrible one, but false convictions are abhorrent. Often the evidence does not support a finding of guilt or innocence with sufficient clarity to allow a decision free of gnawing doubt. In many cases, a large part of the problem is that the prosecution's case depends critically on the statement or testimony of a young child. Even with respect to adult witnesses, the law of hearsay and confrontation is very perplexing, as anyone who has studied American evidentiary law and read Supreme Court opinions on the subject knows. Juxtaposing problems of hearsay and confrontation with those of child sexual abuse yields one of the most intractable problems that a system of criminal justice can face.

II

\section{RESTRUCTURING THE General LAW OF CONFRONTATION AND HEARSAY}

I do not believe that our criminal justice system can reach a satisfactory resolution of the problems inherent in adjudicating claims of child abuse until it restructures the general law of confrontation and hearsay. ' In Lilly v. Virginia, ${ }^{2}$ I co-authored an amicus brief for the American Civil Liberties Union proposing a reconceptualization of the confrontation right. ${ }^{3}$ Justice Breyer, one of the

\footnotetext{
Copyright $\odot 2002$ by Richard D. Friedman

This article is also available at http://www.law.duke.edu/journals/65LCPFriedman.

* Ralph W. Aigler Professor of Law, University of Michigan.
}

1. I include here only a brief summary of my views on this topic, as I have written extensively on it in recent years. See, e.g., Richard D. Friedman, Confrontation Rights of Criminal Defendants, in PROCEEDINGS OF THE FIRST WORLD CONFERENCE ON NEW TRENDS IN CRIMINAL INVESTIGATION AND EVIDENCE 533, 533-41 (Johannes F. Nijboer \& J.M. Reijntjes eds., 1997); Richard D. Friedman \& Bridget McCormack, Dial-In Testimony, 150 U. PA. L. REV. (forthcoming 2002); Richard D. Friedman, Thoughts from Across the Water on Hearsay and Confrontation, 1998 CRIM. L. REV. 697 (1998); Richard D. Friedman, Truth and Its Rivals in the Law of Hearsay and Confrontation, 49 HASTINGS L.J. 545 (1998); Richard D. Friedman, Confrontation: The Search for Basic Principles, 86 GEO. L.J. 1011 (1998); Richard D. Friedman, Confrontation and the Definition of Chutzpa, 31 ISRAEL L. REV. 506 (1997); Richard D. Friedman, Lilly v. Virginia: Glimmers of Hope for the Confrontation Clause?, in INT'L COMMENT. ON EVIDENCE (2000), available at http://www.law.qub.ac.uk/ice.

2. 527 U.S. $116(1999)$.

3. Brief of Amici Curiae American Civil Liberties Union, Lilly v. Virginia, 527 U.S. 116 (1999) (No. 98-5811). 
members of the plurality in that case, wrote a concurring opinion referring extensively to the brief and expressing considerable sympathy for the views advanced in it. These views are in many ways compatible with those of Justices

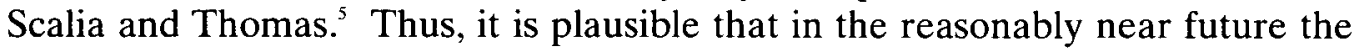
Court will revamp the Confrontation Clause along the lines suggested in the amicus brief.

The current doctrine depends largely on the Court's perception that hearsay law and the confrontation right "are generally designed to protect similar values and stem from the same roots." Thus, the Court has tended to meld the two, treating both as aimed at facilitating accuracy in truth-finding by weeding out unreliable evidence. With respect to out-of-court statements, therefore, the Court has given the confrontation right very little ambit independent of hearsay law. If a statement fits within a "firmly rooted" hearsay exemption, then the Confrontation Clause is unlikely to pose an obstacle to admissibility. ${ }^{8}$ As a result, whether a statement by a child alleging sexual abuse should be admitted at the trial of the alleged abuser often depends on whether the court deems the statement to fit within one of the hearsay exemptions listed in the Federal Rules, a list purportedly determined by considerations of reliability. ${ }^{9}$ This approach is objectionable on numerous grounds.

4. 527 U.S. at 137 (Breyer, J., concurring).

5. Like Justice Thomas's concurring opinion in White v. Illinois, 502 U.S. 346, 358 (1992), in which Justice Scalia joined, Justice Breyer's concurrence in Lilly indicated that the confrontation right should not extend to all hearsay statements, but only to those made by persons deemed "witnesses" under the Sixth Amendment. 527 U.S. at 142. Justice Scalia also wrote a short concurrence in Lilly, indicating that he regarded the case as presenting a "paradigmatic" confrontation violation, 527 U.S. at 138 , a conclusion that Justice Breyer's analysis would support.

6. Ohio v. Roberts, 448 U.S. 56, 65 (1980).

7. Inclusion in the Federal Rules of Evidence seems to qualify an exemption, and the bounds of that exemption, as firmly rooted. See White v. Illinois, 502 U.S. 346, 355 n.8 (1992). In White, the Court held that the hearsay exceptions for spontaneous declarations and for statements made for purposes of medical diagnosis or treatment are "firmly rooted" for purposes of the Confrontation Clause. The latter exception is of relatively recent vintage, but the Court noted that it is "recognized in Federal Rule of Evidence 803(4), and ... widely accepted among the States." Id. But the drafters of the Federal Rule, though not creating the exception out of thin air, did much more than simply reflect the preexisting law. Instead, they expanded the bounds of the exception. It was only by virtue of one of those expansive choices-allowing the exception to cover statements describing the "inception or general character of the cause [of the medical condition] insofar as reasonably pertinent to diagnosis or treatment"-that the statements in White fit within the hearsay exception. RICHARD D. FRIEDMAN, THE ELEMENTS OF EVIDENCE 260, 324 (2d ed. 1998).

8. In Roberts, the Court said that the Confrontation Clause ordinarily allows admission of a hearsay statement by a declarant not present at trial and subject to cross-examination only if the declarant is unavailable. Roberts, 448 U.S. at 63 . In subsequent cases, the Court has declined to apply this unavailability requirement to statements that fit within hearsay exemptions not requiring unavailability. See White v. Illinois, 502 U.S. 346, 353-57 (1992); United States v. Inadi, 475 U.S. 387, 400 (1986).

9. FED. R. EVID. 803(4). 


\section{A. The Difficulties of Determining Reliability}

Reliability is very difficult to determine. To confirm this point, we need look no further than the current debate over the reliability of child witnesses. ${ }^{10}$ Any attempt to sort out reliable from unreliable evidence must run aground. If the determination is made according to broad categories of evidence, the law will be too blunt - not only sweeping in many statements that are not reliable, but also basing decisions on generalizations that may have little bearing on the particular case. If the determination is made case by case, it will not necessarily be any better. The determination will inevitably be very subjective, and it will be either effectively immune from appellate control or extremely demanding on appellate resources.

As an example of how reliability testing does not work, consider the decision of the Court of Appeals for the Tenth Circuit on remand in United States $v$. Tome." The court held that a five-year-old girl's statements to pediatricians alleging that her father had sexually abused her more than a year before were within the hearsay exception. ${ }^{12}$ Because the identity of the perpetrator was important information in determining whether there was a risk of sexually transmitted disease, the court concluded that the statements were made for purposes of medical diagnosis and treatment, and therefore reliable for purposes of the Confrontation Clause. ${ }^{13}$ This is a most unsatisfactory way to determine admissibility. The broad premise of the hearsay exception-that statements made for the purposes of medical diagnosis or treatment are reliable ${ }^{14}$ because a declarant would not want to endanger her health by giving false information-is dubious enough, given the frequency with which patients lie to their doctors. Even accepting that premise, it is simply nonsense to conclude that the particular statements at issue were reliable for the reasons stated by the Tenth Circuit. Can one really believe that a five-year-old girl almost certainly recognizes the importance of identifying the person who abused her (assuming abuse did occur) more than a year earlier, because otherwise she would risk not being properly treated for sexually transmitted disease?

\section{B. The Inappropriateness of the Reliability Criterion}

More significantly, even if we had a sound way of determining reliability, it would be an unsuitable criterion for determining admissibility. Trials should not be based on winnowing evidence to that which is reliable before presentation to the fact-finder. ${ }^{15}$ Rather, trials are attempts to determine the truth from

10. See Thomas D. Lyon, The New Wave in Children's Suggestibility Research: A Critique, 84 CORnEll L. REV. 1004 (1999); Stephen J. Ceci \& Richard D. Friedman, The Suggestibility of Children: Scientific Research and Legal Implications, 86 CORNELL L. REV. 33, 76-81 (2000).

11. 61 F.3d 1446 (10th Cir. 1995) (on remand).

12. Id. at 1449 .

13. Id. at 1449 .

14. FED. R. EVID. 803(4).

15. In recent years, however, use of reliability as a criterion for admissibility has not been limited to the realm of confrontation and hearsay. Reliability has become the principal criterion stated by the 
an aggregation of evidence, some of which may be very unreliable. Live testimony under oath and subject to cross-examination-the paragon of acceptable evidence-is not necessarily reliable; that is why we have conflicting testimony at trial.

One might contend, though, that reliability acts as a sufficient proxy for these conditions. If a statement is so reliable that there is virtually no doubt about its truth, the argument runs, then we can overlook the fact that it was not made under the conditions we usually expect of testimony. This argument is not persuasive, however. In order for the court to accept an out-of-court statement as essentially conclusive, it would have to be extraordinarily reliable indeed. There would have to be no more than a minuscule possibility that the statement would have been made if it were untrue. Despite continued expressions of optimism on this score ${ }^{16}$ one really cannot have such faith in any broad category of statements. Statements by children are no different. If a child makes a statement alleging that the accused abused her, then in most circumstances the probability that she would have made the statement even though it was false, though perhaps small, is potentially large enough to be of concern.

Suppose, to take a simple numerical example, that apart from the allegation of abuse made by a child, the factfinder would assess the odds that the defendant is guilty of abuse to be one-to-two. In other words, though other evidence makes guilt appear plausible, it appears about twice as likely that the defendant is not guilty. Suppose further that the factfinder estimates that if the abuse occurred, the probability that the child would say that it did is seventy percent, and that if the abuse did not occur the probability that the child would nevertheless say that it did is only five percent. ${ }^{17}$ Then, given the allegation, the factfinder should assess the odds that the defendant committed the abuse as seven to one, ${ }^{18}$ which is plainly insufficient for conviction. ${ }^{19}$ If the odds of guilt as assessed without the child's statement are significantly lower, as they may be in a

Supreme Court for the admissibility of expert evidence in Daubert v. Merrell Dow Pharms., Inc., 509 U.S. 579 (1993). The Court has also said that "reliability is the linchpin in determining the admissibility of identification testimony." Manson v. Braithwaite, 432 U.S. 98, 114 (1977).

16. Note, for example, the endorsement by the Supreme Court, per Justice O'Connor, of the hearsay exception for dying declarations on the ground that a declarant "who is immediately going into the presence of his Maker" is "highly unlikely" to do so "with a lie upon his lips." Idaho v. Wright, 497 U.S. 805, 820 (1990) (quoting Queen v. Osman, 15 Cox Crim. Cas. 1, 3 (Eng. N. Wales Cir. 1881) (Lush, L.J.)).

17. These numbers, though presented for heuristic purposes only, are quite realistic. For example, in one leading study, thirty-one of thirty-six girls $(86 \%)$ who had been subjected to a vaginal touch during a pediatric exam and twenty-five of thirty-six girls $(69 \%)$ who had been subjected to an anal touch correctly answered that they had been subjected to these touches when asked directly about them with the aid of anatomical dolls. One girl out of thirty-five $(2.86 \%)$ whose vagina had not been touched during the exam answered affirmatively when asked about a genital touch, and two out of thirty-six $(5.56 \%)$ answered affirmatively and incorrectly when asked about an anal touch. See Karen J. Saywitz et al., Children's Memories of a Physical Examination Involving Genital Touch: Implications for Reports of Child Sexual Abuse, 59 J. CliniCAL \& CONSUlTing PSYCH. 682, 686-87 (1991).

18. Under Bayes' Theorem, to determine the odds of guilt given the allegation (the posterior odds), the factfinder should multiply the odds of guilt as assessed without taking the allegation into account (the prior odds) by the likelihood ratio of the allegation with respect to guilt. The likelihood ratio is the probability that the allegation would be made given that the defendant is guilty, divided by the 
case largely dependent on that statement, so too will the odds given that statement. If, as assessed apart from the child's statement, the odds that the defendant is guilty appear quite small and there is more than a minuscule probability that the child would make the statement despite the defendant's innocence, then the odds of guilt, even given the statement, will not be sufficient to support a conviction.

\section{The Essence of the Confrontation Right}

Most fundamentally, the focus on reliability misses the point of the confrontation right. The Confrontation Clause is not a constitutionalization of the law of hearsay, with all its oddities. It does not speak of reliability or of exceptions. The confrontation right reflects a belief, central to our system of criminal justice, that a witness against a criminal defendant should give testimony under prescribed conditions-under oath, in the presence of the accused, subject to cross-examination, and, if reasonably possible, in open court. And this right should be recognized-as the language of the Confrontation Clause suggestsas categorical and not subject to exceptions. When a witness testifies in court for the prosecution, the court does not tell the accused, "This testimony was so reliable that you really have no need to cross-examine." The same should be true when a person acts as a witness by making a testimonial statement out of court that is later offered against the accused.

Under this approach, the confrontation right extends not to all hearsay statements but only to those made by "witnesses" against the accused. Put another way, to come within the Confrontation Clause, a statement must be testimonial in nature. What makes a statement testimonial? That, of course, can be a very difficult question. The right is meant to prevent the creation of a system in which witnesses can provide evidence for prosecution of a crime without submitting themselves to cross-examination under oath in the presence of the accused. $^{20}$ Basically, if an out-of-court declarant knows that she is probably providing evidence toward investigation or prosecution of a crime, then she is

probability that the accusation would be made given that the defendant is not guilty. Thus the posterior odds equal $1 / 2 \times .7 / .05=7$, or $7: 1$. For further discussion and hypotheticals along these lines, see Ceci \& Friedman, supra note 7 , at 76-81.

19. See Schlup v. Delo, 513 U.S. 298, 325 (1995) (quoting THOMAS STARKIE, EvidenCE 751 (1824) ("It is better that ninety-nine ... offenders shall escape than that one innocent man be condemned.")).

20. I do not address here the question whether the right should be deemed satisfied by a procedure such as that permitted by Maryland v. Craig, 497 U.S. 836 (1990). There, the child witness testified via one-way closed-circuit television from a location other than the courtroom. The accused was in the courtroom but in electronic communication with counsel, who was at the remote location and able to examine the witness face to face. The court held that such a procedure was permissible if the prosecution made an adequate showing that it was necessary to prevent trauma to the child that would arise from testifying in the presence of the defendant. For an argument that fear of trauma is not a sound reason for allowing such a procedure, see Friedman, Confrontation and the Definition of Chutzpa, supra note 1, at 532-33. Such a procedure may be justified, though, if the accused's wrongful conduct has intimidated the child from testifying in the conventional manner. See infra Part IV. 
testifying ${ }^{21}$ if the law permitted admissibility of the statement, then this would be a means for her to present evidence without submitting to the usual conditions of testimony. If the declarant makes an accusation to the authorities, then presumably - in the case of adults - it is a testimonial statement. Testimony, however, should not be limited to statements made directly to the authorities, ${ }^{22}$ for witnesses can speak through intermediaries who can then pass on the testimony.

In most cases, it is reasonably clear whether a statement should be considered testimonial. If it is, the confrontation right should attach and categorically bar admissibility of the statement unless the accused has had an adequate opportunity to examine the witness. ${ }^{23}$ Like almost any right, however, the confrontation right should be considered subject to forfeiture by misconduct. If wrongdoing of the accused accounts for the unavailability of the witness, then the accused cannot complain that his confrontation right renders improper use of a statement made by the witness not under the usual conditions for testimony. ${ }^{24}$

Once the nature of the confrontation right is recognized, and the right is protected by a doctrine independent of the law of hearsay, the importance of hearsay law diminishes vastly. No longer is there a need for a broad presumptive rule of exclusion with a long list of exemptions. Instead, courts should recognize that if live testimony of the declarant would be more probative than prejudicial, usually the hearsay would be as well. ${ }^{25}$ When, therefore, hearsay has significant probative value and does not raise confrontation problems, courts should generally be receptive to it, excluding it only for a good reason, such as that exclusion will induce the production of better evidence, either in this case or over the long run.

21. This article will refer to defendants as masculine and to victims, witnesses, and declarants as feminine. This convention assists clarity and also reflects the reality that in child abuse prosecutions the defendant is most likely to be male and the alleged victim most likely to be female.

22. In this respect, I depart from the theory advanced by Justice Thomas in his concurring opinion in White v. Illinois, 502 U.S. 346, 358 (1992), and also from that offered by Professor Amar. AKHIL R. AMAR, THE CONSTITUTION AND CRIMINAl PROCEDURE: First PrinCiPles 124-31 (1997); Akhil R. Amar, Foreword: Sixth Amendment First Principles, 84 GEO. L.J. 641, 688-97 (1996). See generally The Search for Basic Principles, supra note 1.

23. If the accused has had such an opportunity, but significantly after the time of the statement, the prior statement often should be deemed inadmissible. The principal reason is that if the prior statement contains information that the current testimony does not, the accused's opportunity to examine the witness with respect to that information is likely to be significantly impaired. See generally Richard D. Friedman, Prior Statements of a Witness: A Nettlesome Corner of the Hearsay Thicket, 1995 SUP. CT. REV. 277 (1995).

24. This forfeiture principle, which is of very long standing, has recently been recognized in the context of the Federal Rules of Evidence by the adoption of Rule 804(b)(6).

25. Empirical evidence suggests that jurors do not fail to discount hearsay evidence for its weaknesses. See, e.g., Margaret Bull Kovera et al., Jurors' Perceptions of Eyewitness and Hearsay Evidence, 76 MINN. L. REV. 703, 720-22 (1992). Indeed, there is suggestion that in some circumstances jurors may discount hearsay too much rather than too little. See Peter Miene et al., Juror Decision Making and the Evaluation of Hearsay Evidence, 76 MINN. L. REV. 683, 695 (1992). 


\section{The Basic Framework}

The discussion above suggests the basic framework that should govern the law of confrontation and hearsay. It does not leave room for anything like the hearsay exceptions-no attempts to distort the exceptions for excited utterances or statements made for medical diagnosis to accommodate statements by children or other declarants. ${ }^{26}$ Instead, one should ask first whether the statement was testimonial in nature. If so, then the confrontation right attaches categorically. Thus, the statement must be excluded, unless the accused has had an adequate opportunity to examine the witness-or unless the reason the accused has not had such an opportunity is attributable to the accused's own wrongdoing. If the statement was not testimonial, then the confrontation right does not apply and presumably the statement ought not be excluded if it is significantly probative. Nevertheless, other considerations, particularly the possibility of inducing the presentation of better evidence, might yet require the exclusion of the evidence.

At the most general level, this framework should be applied to statements by children as well as to those by adults. Of course, the application must be sensitive to context, so the results may be profoundly affected by the fact that the declarant is a child. Two questions will often be particularly important in the case of children: Was the statement testimonial? Did the accused forfeit the right to confront the child?

\section{III}

\section{IS THE STATEMENT TESTIMONIAL?}

Suppose a ten-year-old child of ordinary intelligence makes a statement to an investigative social worker accusing an adult of sexual abuse. Under the approach I have advocated here, it is clear that she is acting as a witness against the accused, just as if she were an adult, and the confrontation right attaches to her statement. Thus, if she does not testify subject to oath and crossexamination, then her statement should not be admitted unless the accused is held to have forfeited the confrontation right.

The same result would presumably follow if, instead, the child made the statement to her mother. The child would presumably realize that her mother would likely take responsive conduct that might have significant punitive consequences for the accused. In this setting, the child should be deemed to be testifying as if she were an adult and as if she had made her statement in court rather than through an intermediary.

Now consider a polar opposite case: Suppose a bloodhound barks at the accused, effectively identifying him as the source of an item of clothing. Evidence

26. See White v. Illinois, 502 U.S. 346, 355 n.8 (1992) (holding hearsay exceptions for spontaneous declarations and for statements for medical treatment to be firmly rooted for purposes of the Confrontation Clause). 
of the bloodhound's conduct may very well be admitted, yet we would not dream of excluding it because the bloodhound cannot be cross-examined. ${ }^{27}$

Given these two polar treatments, how should the law of confrontation treat a statement by a very young child alleging abuse? It is tempting to conclude without analysis that, given that the child is a human, she should be treated as a witness, like adult humans or older children who make statements alleging criminal conduct. This may not be the appropriate result, however.

Suppose a child is so young that she has no sense that what she is reporting is wrongful conduct-if, in fact, her words are properly understood as a report of conduct that adults know to be wrongful - and no sense that the person she identifies as the perpetrator is subject to punishment for it. Consider, for example, these two cases:

1. Webb: An eighteen-month-old girl, on being lowered into the bath, said, "Ow bum," and then after the bath, while her mother was examining her, "Ow bum daddy." 28

2. Rhea: A two-and-one-half year-old child was interviewed by a child protection specialist of the Department of Human Resources. In response to questions, she denied that her father had done anything wrong to her, but she nodded in agreement to the question, "Did daddy make you put his tee-tee in your mouth?",29

It seems dubious to say that the children in these cases were acting as witnesses. Without some sense of social organization that would be beyond the understanding of children so young, they could not have understood that they were providing information that could lead to the punishment of their fathers, who presumably they regarded as being virtually immune to punishment. Indeed, it appears that the child in Rhea did not regard the conduct as wrongful, and the same may be true of the child in $W e b b$. Certainly these children were providing information, but people do that all the time-completing business records, advancing conspiracies, and so forth-without the communication being testimonial. It is doubtful that the children's communications in these cases should be considered testimonial.

That conclusion is weaker in Rhea than in $W e b b$, not only because the child was older, but also because her communication was elicited by a state officer. ${ }^{30}$ At the very least, such elicitation is a factor to be taken into account in determining the level of the child's understanding. It is possible that a child would not, and perhaps could not, have made a testimonial statement on her own initiative but still would have enough understanding of the nature and purpose of the questioning that her responses should be characterized as testimonial.

27. See generally Andrew E. Taslitz, Does the Cold Nose Know? The Unscientific Myth of the Dog Scent Lineup, 42 HASTINGS L.J. 17 (1990) (reviewing cases involving "dog scent lineup" evidence and concluding that the courts have been too receptive to it).

28. State v. Webb, 779 P.2d 1108, 1109 (Utah 1989).

29. Rhea v. State, 705 S.W.2d 165, 171 n.1 (Tex. Ct. App. 1985) (Cornelius, C.J., dissenting).

30. Rhea, 705 S.W.2d at 166. 
Arguably, though, a broader proposition should prevail - that elicitation by the state is, in itself, enough to treat a person's statement as testimonial. ${ }^{31} \mathrm{We}$ might be made wary of drawing that conclusion by the fact that, if consistently applied in the adult realm, it would presumably render subject to the Confrontation Clause many statements made by conspirators of the accused who did not know that their listeners were informants or undercover police officers. Even if the government is trying to draw information from a source, that does not mean that the source should be deemed to be testifying. Indeed, prosecutorial authorities often try to elicit information from non-human sources, and the information they gain cannot be characterized as testimonial. There is no persuasive reason to treat differently the human source who, while recognizing that she is providing information in the course of a conversation, does not regard the conversation as testimonial in nature.

If the communications in cases like Rhea and Webb are considered nontestimonial, then the confrontation right, as described in Part II, should not apply. The statements should not necessarily be admitted, however. A court might determine that the methods of questioning by authorities were so unduly suggestive that they should not be countenanced. Such a decision would be motivated largely by the desire to deter future investigators from acting in such an irresponsible way. Alternatively, the court might conclude that the authorities failed to follow procedures, such as videotaping the interview, to which professionals, repeat players in the process, should be expected to adhere. ${ }^{32}$ The court might even hold that the evidence could have been rendered more satisfactory if the investigators had allowed a representative of the defendant to take part, perhaps not by formal questioning of the child, but by helping to plan the interview and suggesting follow-up questions. Indeed, such participation might be more productive than cross-examination in court, which is typically uninformative and a grueling, frustrating, and stressful affair for all concerned.

There may appear to be a paradoxical aspect to the theory advanced here. The theory suggests that the younger and less mature and understanding a child is, the less likely her statement should be considered testimonial, subject to the Confrontation Clause, and therefore, all other things being equal, the more likely the statement should be admitted. This conclusion, however, is really not paradoxical at all. Even statements by very young children may be highly probative. But very young children are not yet at a stage where they can be expected to take the responsibility of being a witness-the responsibility of speaking under oath, subject to questioning by the accused, under the implicit injunction, "Look me in the eye and say that." ${ }^{33}$ With respect to very young

31. See generally Margaret A. Berger, The Deconstitutionalization of the Confrontation Clause: $A$ Proposal for a Prosecutorial Restraint Model, 76 MiNN. L. REv. 557, 561-63 (1992) (emphasizing the role of prosecutorial elicitation of evidence in a theory of the Confrontation Clause).

32. See, e.g., Ceci \& Friedman, supra note 1, at 103-06; Lucy F. McGough, Good Enough for Government Work, 65 LAW \& CONTEMP. PROBS. 179 (2002).

33. Coy v. Iowa, 487 U.S. 1012, 1018 (1988) ("The phrase still persists, 'Look me in the eye and say that."'). 
children-I will not try to say here just how young-we should admit their statements for what they are worth, without pretending that the children have the capacity to act like adults. ${ }^{34}$

\section{IV}

\section{DiD THE ACCUSED FORFEIT HIS RIGHT TO OBJECT?}

The forfeiture principle prescribes that if the accused's own wrongful conduct is responsible for the inability of the witness to testify under the conditions ordinarily required, the accused cannot object to use of the witness's prior statement. ${ }^{35}$ This principle is well established as a matter of confrontation and hearsay law, and it potentially has an important, though difficult, role to play in child abuse cases. It is plain enough that the forfeiture principle is not rendered inapplicable when the witness who was prevented from testifying at trial is the victim of the crime being charged. ${ }^{36}$ The same logic should be taken one step further: The forfeiture principle remains applicable even when the conduct that allegedly rendered the witness unavailable to testify is the same criminal conduct for which the accused is now on trial. ${ }^{37}$

At first glance, this application of the forfeiture principle might seem to be a bizarre instance of bootstrapping. But it is not. Suppose, as would usually be so, that the case is being tried by a jury. For purposes of deciding whether the forfeiture principle applied, the judge would determine whether the accused had committed misconduct rendering the witness unable to testify. The result would be either admission or exclusion of the prior statement, but either way the judge would not have to explain her decision to the jurors and so would not need to inform them that she had made a determination as to whether the accused had committed misconduct. The jury would decide guilt or innocence of the crime. Thus, even if the judge and jury had to decide the same factual issue, the reasons why that issue was presented to them would be different, and they would make their findings independently. Furthermore, the two factfinders would decide according to different bodies of evidence ${ }^{38}$ and different standards

34. I mean to leave somewhat ambiguous the question whether the lack of capacity that might cause a young child not to be deemed a witness is merely cognitive or one of moral responsibility. Is the critical deficiency that the child does not understand the consequences of her utterance? Or is it, as my University of Michigan colleague Sherman Clark has emphasized in conversation, that the childperhaps because of a lack of understanding of consequences - is not responsible for making a choice to testify? I have not fully resolved this issue in my own mind. For present purposes, it is not necessary to resolve it. The key point is that, whatever the precise nature of the critical capacity may be, at some point a child will be insufficiently mature to be deemed a witness.

35. As noted above, the forfeiture principle is now expressed in Fed. R. Evid. 804(b)(6). For further discussion of the principle, see generally Friedman, Confrontation and the Definition of Chutzpa, supra note 1 .

36. Friedman, Confrontation and the Definition of Chutzpa, supra note 1, at 521. Nothing in the language of Rule $804(\mathrm{~b})(6)$ suggests that it is rendered inapplicable if the declarant is the victim of the crime.

37. See Friedman, Confrontation and the Definition of Chutzpa, supra note 1.

38. Most of the rules of evidence would not apply to the judge. FED. R. EVID. 104(a). 
of proof. ${ }^{39}$ The situation is closely analogous to that of a judge presiding over a conspiracy trial who decides that a statement may be admitted because it was made during the course of and in furtherance of a conspiracy-the very conspiracy being tried-of which the accused was a part. ${ }^{40}$

Suppose that a child makes a statement alleging abuse and that the prosecutor, with the cooperation of the child's caretakers, makes a genuine effort by appropriate means to get the child to testify, but she fails to do so. Suppose that it appears the child may have been intimidated, either by the abusive conduct itself or by a threatening statement-"Don't tell anyone!"-that accompanied or followed the conduct. In such a case, it may be appropriate to apply the forfeiture principle."

The difficulties of applying the forfeiture principle in the context of child abuse are, I concede, substantial. First, as in any case in which the principle is invoked, the court must resolve a basic question that is often very difficult: Did the accused actually commit, or acquiesce in, the wrongful conduct that assertedly rendered the witness unavailable? But in the case of a child witness, the complexities only begin there. Another issue the court must resolve is whether, assuming the accused committed the conduct, that conduct really accounts for the child's silence. One alternative explanation may be that the cause is merely the child's age and immaturity. If that is so, then, assuming the confrontation

39. At least as a constitutional matter, the judge would not be held to the "beyond a reasonable doubt" standard. See Lego v. Twomey, 404 U.S. 477, 488-89 (1972) (holding that, for determination of whether a confession was voluntary, a standard stricter than preponderance of the evidence is not constitutionally necessary, though states are free to adopt a higher standard as a matter of state law); United States v. Mastrangelo, 693 F.2d 269, 273 (2d Cir. 1982) (declining "to impose upon the government more than the usual burden of proof by a preponderance of the evidence where waiver by misconduct is concerned"); $c f$. Bourjaily v. United States, 483 U.S. 171, 175 (1987) (stating that the Court has "traditionally required" that "admissibility determinations that hinge on preliminary factual questions ... be established by a preponderance of proof"); United States v. Thevis, 665 F.2d 616, 630-31 (5th Cir.), cert. denied, 459 U.S. 825 (1982) (adopting standard of "clear and convincing evidence" in forfeiture context).

40. See, e.g., Bourjaily v. United States, 483 U.S. 171 (1987). In Bourjaily, one of the charges against the defendant was a conspiracy count. Among the evidence offered against him was a statement made by another person and offered by the prosecution under the hearsay exemption for statements by conspirators of an adverse party. FED. R. EVID. 801(d)(2)(E). Applicability of the exemption depended upon preliminary determinations by the trial court that Bourjaily and the declarant were indeed conspirators and that the statement was made during the course of and in furtherance of the conspiracy. In that respect Bourjaily is typical of cases involving the exemption. The most notable aspect of the case is the Court's holding that, in making the preliminary determinations of whether a conspiracy existed and whether the defendant was a part of it, courts could rely in part on the statement itself; Rule 104(a) overrides the prior rule against "bootstrapping," under which courts could rely only on independent evidence in making these determinations. Bourjaily, 483 U.S. at 176-81.

41. In at least one case, the court has applied the forfeiture principle in such a situation. State v. Sheppard, 484 A.2d 1330, 1345-48 (N.J. Super. 1984) (holding the confrontation right inapplicable because defendant threatened to kill child victim of sexual abuse if she revealed his activities). $C f$. State v. Jarzbek, 529 A.2d 1245, 1253 (Conn. 1987) ("Here,... although the threats made by the defendant against the minor victim were... designed to conceal his wrongdoing, they were made during the commission of the very crimes with which he is charged.... The constitutional right of confrontation would have little force ... if we were to find an implied waiver of that right in every instance where the accused, in order to silence his victim, uttered threats during the commission of the crime for which he is on trial."). 
right applies - whether in accordance with or despite the views expressed above in Part II-the accused should not be deemed to have forfeited the right. Perhaps the judge's task should be seen as determining whether the child would be willing and able to testify about a matter that she did not find especially troubling. ${ }^{42}$ If she would not be, then presumably it was not the accused's wrongful conduct that accounts for the child's silence, and there should be no forfeiture. I do not pretend that resolving this issue would be a simple matter. ${ }^{43}$

In some cases, the court may also have to resolve whether the child's failure to testify is attributable not to her own fears but to the desire of her caretaker, who-perhaps in a desire to protect her from trauma, perhaps from other motives-has refused to make the child available to testify or has instructed her not to testify. In such a case, the child should probably not be deemed unavailable by virtue of the defendant's wrongdoing. Thus, the judge, or an expert appointed by the judge, may need to speak with the child to try to determine whether the child's own fear, or some other influence, is preventing her from testifying under suitable conditions. ${ }^{44}$

Finally, there is a question of remedy. Suppose the court concludes that the child should be deemed unavailable to testify in court under ordinary procedures, and that this unavailability should be attributed to the accused's wrongful conduct. There remains the issue of what steps, if any, the prosecution must take, as a prerequisite to introducing secondary evidence of the prior statement, to preserve as much as possible of the confrontation right. For example, perhaps even though the child is unable to testify in the courtroom at trial she could, or could have, testified in a less intimidating setting, perhaps without the accused present in the room where she testifies but instead electronically con-

42. This hypothetical question is not self-evidently the correct standard. Alternatively, and more favorably to the accused, one might ask: Would the child testify about a matter such as a hurricane that, although disturbing, did not involve wrongful conduct? Part of the wrong that the accused assertedly committed, however, was introducing a disturbing influence into the child's life. If the accused did so and the child is unable to testify because the impact was so disturbing to her, then arguably that inability should be attributed to the accused.

43. Current law also sometimes calls on courts to make extremely subtle findings. See Maryland v. Craig, 497 U.S. 836, 855-56 (1990) (holding that testimony by electronic connection may be permissible when the court finds that the particular child witness "would be traumatized, not by the courtroom generally, but by the presence of the defendant" and that the finding of necessity must be "casespecific").

44. I have previously suggested that, if the prosecution uses the same coercive measures against the caretaker that it would use if the caretaker were the witness, and the court is persuaded that the caretaker's refusal to allow the testimony is attributable to the defendant's wrongdoing, then the case should probably be treated as if the caretaker were the declarant and was intimidated by the defendant. See Friedman, Confrontation and the Definition of Chutzpa, supra note 1, at 534 n.60. On further reflection, though, I think that is probably not a good rule. It would involve a most distasteful use of the state's coercive power, sinking the court further into deciding imponderable factual issues, and potentially allowing collusion and strategic game-playing by the prosecutor and caretaker. There is, of course, the possibility that the caretaker would say, in effect: "In order to protect the child from further trauma, I have to prevent her from testifying." Then the proper judicial response would be to say, in effect: "There is no good reason to believe the child is likely to suffer long-term trauma if she does testify. But you may persist in not allowing her to testify, and we will not try to compel you. Be aware, though, that her prior statement will not be admissible, and the prosecution might be lost for that reason." 
nected to it, and with a video transmission or recording of her testimony presented in the courtroom at trial. ${ }^{45}$

\section{V \\ CONCLUSION}

This article began with the assertion that adjudicating claims of child abuse poses an excruciatingly difficult conundrum, and it will end in the same way. I do not pretend that there are any easy answers, or at least any satisfactory easy answers, to the problem of determining when a child's statement alleging abuse should be admitted notwithstanding hearsay law and the accused's confrontation right. It is clear enough, however, that the method by which we have approached the problem-relying on the prevailing structure of hearsay law and pretending to determine reliability-is utterly inadequate. And so we must think anew.

Under the approach presented here, we would first ask: Was the statement testimonial, so that the child was effectively acting as a witness in making the statement? If so, then presumably the statement should not be admitted unless the accused has had an adequate opportunity to examine her, or unless the accused is deemed to have forfeited his objection by wrongful conduct that prevented the child from testifying. If the statement was not testimonial, then the confrontation right should not block its admission. Exclusion may yet be warranted, though, by failure of the authorities to follow procedures, such as videotaping an interview, that would allow the evidence to be scrutinized in a satisfactory way. In many cases the questions posed here will be very hard to answer. They are, however, the right questions to ask. Trying to answer them will help make the best of a dreadful situation.

45. Such procedures are constitutionally permissible under Maryland v. Craig, 497 U.S. 836 (1990), when there is a danger that the child would be traumatized by giving in-court testimony. As noted above, the merits of that decision are not discussed in this article. In the setting being discussed here, the basis for allowing the procedure would not be fear of trauma, but rather forfeiture of the confrontation right by the accused, given the child's refusal or inability to testify in court and the court's finding that this refusal or inability is attributable to the accused's wrongful conduct. In such a setting, a substitute procedure such as video transmission or recorded testimony is clearly permissible. It is an alternative less restrictive of the accused's confrontation rights than simply admitting the child's prior statement, which was presumably made without oath or any opportunity for cross-examination. Preferably, the testimony should be taken with a two-way hookup so that the child could see as well as be seen by the accused, but if that does not solve the intimidation problem, a one-way hookup should be acceptable, even without relying on Craig. 